F. D'Athis, M. Macheboeuf, H. Thomas, C. Robert, G. Desch, M. Galtier, P. Mares, J. J. Eledjam

\title{
Epidural analgesia with a bupivacaine-fentanyl mixture in obstetrics: comparison of repeated injections and continuous infusion
}

We compared the efficacy and side-effects of continuous infusion versus repeated injections of epidural bupivacainefentanyl during labour. Forty-four parturients were randomly distributed into two groups balanced for population size, morphology and parity. Analgesia was begun at the same stage of labour with a mixture of $20 \mathrm{ml} 0.25$ per cent plain bupivacaine and $2 \mathrm{ml}(100 \mu \mathrm{g})$ fentanyl. In Group I the initial dose ranged from $8-12 \mathrm{ml}$ as a function of height; an injection of the same dose was repeated immediately upon recurrence of pain. In Group II, after an initial dose of $5-7 \mathrm{ml}$, a continuous infusion of $3 \mathrm{ml} \cdot \mathrm{h}^{-1}$ was begun, and continued until full dilatation. Analgesia was rated using a pain scale; effects on maternal blood pressure, respiratory rate and neonatal status were noted. Bupivacaine and fentanyl assays were carried out on maternal venous blood in 30 parturients during the course of labour. There was a longer latency to onset of analgesia in Group II (approximately five minutes), followed by a more constant degree of analgesia. This betler analgesia cannot be accounted for by a difference in dosage; doses were significantly lower in Group II, despite the fact that labour was of the same duration. The course of labour, and maternal and neonatal status were

\section{Key words}

ANAESTHESIA: obstetric; ANAESTHETIC TECHNIQUES: epidural; ANESTHETICS, LOCAL: bupivacaine; ANALGESICS: fentanyl.

From the Département d'Anesthésie Réanimation, CHR Nimes, Nimes, France and the Service de Biochimie, Centre Hospitalier, Avignon, France (GD) and the Laboratoire de Pharmacocinétique-Pharmacie, CHR Nimes, Nimes, France (MG) and the Service d'Obstetrique, CHR Nimes, Nimes, France (PM).

Address correspondence to: Pr. F. D'Athis, Département d'Anesthésie Réanimation, CHR - 5 Rue Hoche, 30006 Nimes, Cedex, France. comparable in the two groups. Assays showed na difference in bupivacaine blood concentrations between the two groups nor signs of drug accumulation. The constant infusion technique is advantageous since it provides a more regular degree of analgesia with lower doses than those required for patients having repeated injections.

Epidural obstetric analgesia requires repeated injections of local anaesthetics even when a long-acting agent such as bupivacaine is used. Addition of fentanyl to the local anaesthetic increases the duration of analgesia; however it does not eliminate the need for reinjections.' Since scheduling of reinjections is a function of recurrence of pain, a sufficient level of analgesia cannot be continuously maintained. Numerous studies have shown the efficacy of continuous infusions for obstetrical analgesia. ${ }^{2,3}$ Along with development of a stable degree of analgesia, the reports stress the limited degree of hypotension and decreased risk of technical accidents (intrathecal or intravascular injection, contamination during manipulations).

Since both bupivacaine and fentanyl cross the placental barrier it is important to determine blood levels of these two agents. Glover, ${ }^{4}$ Evans and Carrie, ${ }^{5}$ Matouskova and Hanson, ${ }^{6}$ Rosenblatt et al. ${ }^{7}$ for bupivacaine, and Cousin et al. ${ }^{8}$ for fentanyl, showed that blood levels were far below the threshold values considered to be toxic. Nevertheless, in a recent editorial, Morison and Smedstad ${ }^{9}$ noted that for comparison of the two techniques, it was necessary to present series carried out under comparable conditions. For example, in the study by Nadeau and Elliott ${ }^{10}$ dosages were very different with the two administration methods, possibly explaining the better results with the continuous infusion.

The purpose of this study is to compare the quality of analgesia, maternal side-effects, effects on the neonate, and matemal blood levels with repeated injections or continuous infusion of bupivacaine and fentanyl. 
TABLE 1 Poin rating seale proposed by Cathelin et al. ${ }^{28}$

\begin{tabular}{|c|c|}
\hline ScorelDescription & Features \\
\hline 5/ Intolerable pain & $\begin{array}{l}\text { Accompanied by shouting, crying, moaning, } \\
\text { psychomotor agitation }\end{array}$ \\
\hline 4 / Severe pain & $\begin{array}{l}\text { While the patient maintains self-control be } \\
\text { feels sufficiently threatened to demand } \\
\text { immediate relief }\end{array}$ \\
\hline 3) Tolerable pain & $\begin{array}{l}\text { Continuous pain of which the patient is } \\
\text { constantly aware }\end{array}$ \\
\hline $2 /$ Mild pain & $\begin{array}{l}\text { Sensation perceived as painful, but which is } \\
\text { occasionally fotgatten }\end{array}$ \\
\hline 1) Very mild pain & $\begin{array}{l}\text { Sensation perceived more as a discomfort } \\
\text { than as actual pain }\end{array}$ \\
\hline 0 i No pain & No sensation of discomfort \\
\hline
\end{tabular}

\section{Methods}

After having given informed consent, 44 parturients were assigned to two groups of 22 via a random number draw. Group I was given repeated injections and Group II continuous infusion of the epidural analgesic mixture. Epidural analgesia was required for patient comfort during labour because of dystocia for trial labour. Matemal characteristics recorded included age, height, weight and parity. After about $100 \mathrm{ml}$ of lactated Ringer's solution was infused, a lumbar epidural blockade was performed with the patient in the sitting position, once the patient was in active labour and the cervix was 3.5 to $4 \mathrm{~cm}$ dilated. Injections were made through a catheter threaded via the $\mathrm{L}_{2}-\mathrm{L}_{3}$ interspace. The patient then assumed the supine position, without a tilted position as a rule, to assure the homogeneous spread of local anaesthetic solution. If a sensory level of $T^{10}$ was not achieved, the patient was tilted head down. After full dilatation, the patient was placed in a semirecumbent pasition.

The mixture included $20 \mathrm{ml}$ of 0.25 per cent plain bupivacaine and $2 \mathrm{ml}$ fentanyl $(100 \mu \mathrm{g})$. Following a test dose of $2 \mathrm{ml}$, parturients in Group I received a dose of the analgesic mixture determined as a function of their height: $8 \mathrm{ml}$ between 150 and $160 \mathrm{~cm}$ and $10 \mathrm{ml}$ for those taller than $160 \mathrm{~cm}$. A dose identical to the initial one was reinjected upon recurrence of pain. Administration was stopped after full cilatation. In Group II, after injection of a $2 \mathrm{ml}$ test dose, patients received a bolus injection half that administered to the preceding group (i.e., 4 or $5 \mathrm{ml}$ ). An infusion of the same mixture was started immediately thereafter at a constant flow rate $\left(3 \mathrm{ml} \cdot \mathrm{h}^{-1}\right)$, previously shown to produce satisfactory analgesia. Administration of the mixture was stopped upon full dilatation.
Quality of analgesia was evaluated using the rating scale proposed by Cathelin (Table I) with a score of 0 equal to complete analgesia (100 per cent) and 5 representing no analgesia ( 0 per cent). Duration of labour was measured between the begianing of the epidural injection and either fuli dilatation or decision to carry out a Caesarean section. The frequency of uterine contractions was determined in both groups from three measures performed in each parturient. The amount of oxytocin required was evaluated by determining the number of drops $\min ^{-1}$ required for an infusion solution containing $10 \mu$ syntocinon in $500 \mathrm{ml}$ five per cent glucose. The number of forceps extractions and Caesarean sections was noted.

Blood pressure, heart rate and respiratory rate were measured at 5 and then 15 min intervals. Adverse effects, including vomiting, dizziness, pruritus and respiratory depression (a rate less than $10 / \mathrm{min}$ ) were documented. After delivery, the condition of the newborn was assessed at 1 and $5 \mathrm{~min}$, using Apgar scores, and at $30 \mathrm{~min}$ using a neuro-sensorial evaluation reported by Amiel-Tison. "I

Total dosages of bupivacaine and fentanyl used in the two groups were calculated. Venous blood samples were taken from 15 parturients of each group for assay of bupivacaine and fentanyl. In Group I, samples were taken 20, 40 and 60 minutes after each injection and upon complete dilation. In Group II, they were taken 20,40, 60,120 and 180 minutes following the initial bolus, and again upon complete dilation.

Bupivacaine was assayed by a high-pressure liquid chromatography assay with a threshold of $0.10 \mu \mathrm{g} \cdot \mathrm{ml}^{-1}$. Fentanyl was assayed by radioimmunoassay with a Fen. RIA. 200 kit supplied by the Belgium National Institute (acceptable precision for levels above $0.1 \mathrm{ng} \cdot \mathrm{ml}^{-1}$ ), providing a detection threshold of $0.02 \mathrm{ng} \cdot \mathrm{ml}^{-1}$ plasma. Statistical analysis was carried out using Student's t test for small groups and by analysis of variance. Dunnett's test $^{12}$ was used to assess the Apgar scores.

\section{Results}

The two groups were similar in terms of age (24.77 \pm 0.92 years for Group I, 26.82 \pm 1.22 years for group II), height $(160.77 \pm 1.08$ and $161.23 \pm 1.11 \mathrm{~cm})$, weight $(66.68 \pm$ 2.63 and $69.95 \pm 2.25 \mathrm{~kg}$ ) and parity (1.14 \pm 0.75 and $1.14 \pm 0.99$ ). Epidural anaesthesia was begun at the same degree of dilatation in the two groups (respectively $3.88 \pm 0.18 \mathrm{~cm}$ and $3.77 \pm 0.21 \mathrm{~cm}$ ).

Analgesia developed more rapidly in Group I (7.30 \pm 0.30 minutes) than in Group II ( $12.57 \pm 0.32$ minutes) $(\mathrm{p}<0.001)$. Development of analgesia is given in the Figure. In both groups analgesia was excellent, without significant differences at $T=15, T=30$ and $T=60$. A 


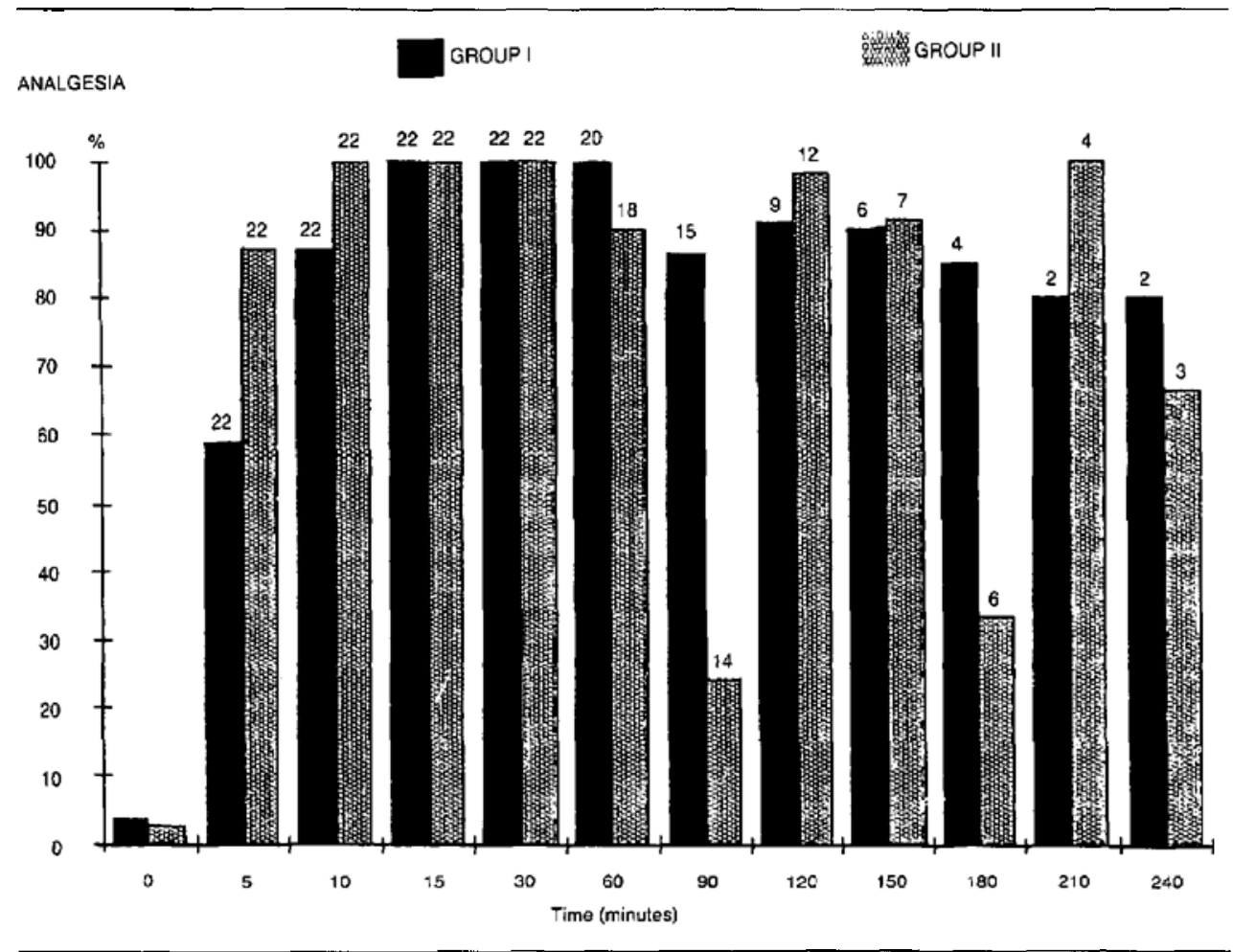

FIGURE Development of analgesia in the two groups (per cent calculated with pain rating scale). Number of patients is given at the top of each column.

difference between the two groups appeared at $T=90$ and became highly significant $(\mathrm{p}<0.001)$ at $\mathrm{T}=180$. Analgesia was better and more constant in Group II than in Group I. In Group I, analgesia upon full dilatation was rated $3.06 \pm 0.82$ after the first injection (delivery of less than 90 minutes duration) and $2.60 \pm 0.41$ after one reinjection (delivery in between 90 to 180 minutes). In Group II, analgesia was rated $1.85 \pm 0.37$ for short labour ( 4 hours) and $1.77 \pm 0.26$ for longer labour. The difference between analgesia scores with the two techniques was significant $(p<0.05$ ) for short labor and highly significant $(p<0.001)$ for longer labor.

There were no significant differences in terms of the course of delivery in the two groups. The mean intervals between two contractions were respectively $175 \pm 2.29$ seconds and $175 \pm 2.25$ seconds, and the rate of infusion of syntocinon was respectively $15 \pm 0.3$ and $15 \pm 0.23$ drops $\cdot \min ^{-1}$. Duration of labour was $139.0 \pm 63.50$ minutes in group $\mathrm{I}$ and $133.63 \pm 54.55$ minutes in group
I. The frequency of forceps extractions was the same in the two groups: forceps were required for three patients in group I and four in group II, Caesarean sections for six in group I and five in group II. The high frequency of forceps and Caesarean sections can be explained by indications of peridural analgesia: only anticipated difficult labour. Blood pressure, heart rate and tespiratory rate show no significant differences. No side effects occurred.

TABLE II Apgar scores at the first and fifth minute

\begin{tabular}{llcll}
\hline Time & Apgar score & Group I & Group II & $P$ \\
\hline 1 minute & $>9$ & $14(64 \%)$ & $15(68 \%)$ & NS \\
& $5-9$ & $7(31.8 \%)$ & $7(31.8 \%)$ & NS \\
& $<5$ & $1(4.5 \%)$ & $0(0 \%)$ & NS \\
5 minutes & $>9$ & $21(95.4 \%)$ & $22(100 \%)$ & NS \\
& $5-9$ & $1(4.5 \%)$ & $0(0 \%)$ & NS \\
& $<5$ & 0 & 0 & \\
\hline
\end{tabular}


TABLE III Maternal bupivacaine and fentanyl blood levels measured after each injection and at complete dilation in Group 1

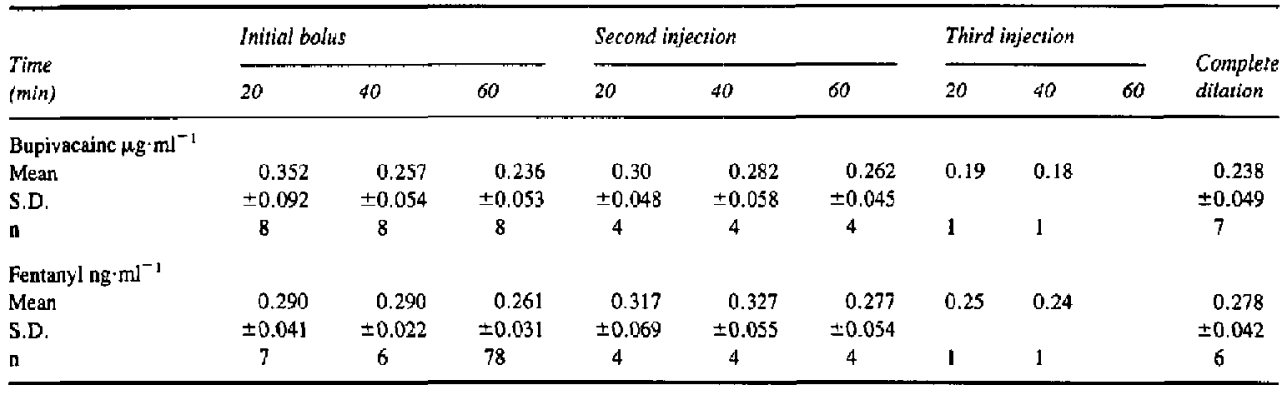

Consumption of the analgesic mixture was calculated as a function of duration of epidural analgesia: $7.70 \pm 1.35$ $\mathrm{ml} \cdot \mathrm{h}^{-1}$ in Group I and $5.32 \pm 0.95 \mathrm{ml} \cdot \mathrm{h}^{-1}$ in Group II. It was significantly shorter in group II than in group 1 (p $<$ $0.001)$. There were no significant differences between the two groups in terms of the Apgar scores (Table II) or of the Amiel test $(27 \pm 0.33$ and $27 \pm 0.36$, respectively for a total score of 30 ?.

Results of assays are shown in Tables III and IV. Assays for bupivacaine and fentanyl during continuous infusion $(20,40,60,120$ and 180 minutes after the bolus) did not show any significant differences. Upon complete dilatation, in Group I the mean bupivacaine blood concentration was $0.238 \pm 0.049 \mu \mathrm{g} \cdot \mathrm{ml}^{-1}$, versus $0.245 \pm$ $0.049 \mu \mathrm{g} \mathrm{ml}^{-1}$ in Group II; the difference between the two groups was not significant. The mean blood fentany] concentration was $0.278 \pm 0.42 \mathrm{ng} \cdot \mathrm{ml}^{-1}$ in Group I and $0.258 \pm 0.038 \mathrm{ng} \cdot \mathrm{ml}^{-1}$ in Group II. The difference between the two groups was also not significant.

\section{Discussion}

Time to onset of analgesia is shortened when fentanyl is combined with bupivacaine, ${ }^{1,13}$ possibly due to rapid uptake of the morphine derivative into the blood 14 and also as fentanyl penetrates into the substantia gelatinosa better than either meperidine or morphine. ${ }^{\text {is }}$ In the present study, time to onset of analgesia in Group I was similar to that recorded by othcr authors: between five and ten minutes. The longer latency in Group II can be explained by the fact that the volume of the initial bolus was smaller than that administered to Group I, or in other studies. The delay was muderate (approximately five minutes) and cannot be considered to be a major drawback. In spite of the absence of a double blind design, after the first ten minutes quality of analgesia was better in Group II than in Group I. With the repeated injection technique, it would seem better to give repeat doses prior to the recurrence of pain, resulting in more steady analgesia, and avoidance of tachyphylaxis. ${ }^{16}$ But because of the unexpected duration of action of the precedent injection, it could procure too frequent injections and excessively high plasma concentrations.

Evars and Carrie ${ }^{5}$ undertook a prospective comparison of repeated injections versus continuous infusion for epidural anacsthesia with bupivacaine alone. They reported that quality of analgesia was clearly superior with the

TABLE IV Matemal bupivacaine and fentanyl blood levels measured during infusion and upon complete dilation in Group II

\begin{tabular}{|c|c|c|c|c|c|c|}
\hline Time (min) & 20 & 40 & 60 & 120 & 180 & $\begin{array}{l}\text { Complete } \\
\text { dilation }\end{array}$ \\
\hline \multicolumn{7}{|c|}{ Bupivacaine $\mu \mathrm{g} \cdot \mathrm{ml}^{-1}$} \\
\hline Mean & 0.199 & 0.204 & 0.193 & 0.320 & 0.240 & 0.245 \\
\hline S.D. & \pm 0.053 & \pm 0.067 & \pm 0.052 & \pm 0.050 & \pm 0.050 & \pm 0.049 \\
\hline n & 7 & 7 & 7 & 5 & 2 & 7 \\
\hline \multicolumn{7}{|c|}{ Fentanyl $\mathbf{n g} \cdot \mathrm{ml}^{-\mathbf{l}}$} \\
\hline Меал & 0.24 & 0.241 & 0.265 & 0.276 & 0.262 & 0.258 \\
\hline S.D. & \pm 0.037 & \pm 0.036 & \pm 0.046 & \pm 0.036 & \pm 0.050 & \pm 0.038 \\
\hline n & 8 & 7 & 8 & 5 & 2 & 8 \\
\hline
\end{tabular}


continuous infusion technique. Nevertheless, the dose infused ( $16 \mathrm{mg} \cdot \mathrm{h}^{-1}$ ) was considerably greater than that used with repeated injections $\left(5 \mathrm{mg} \cdot \mathrm{h}^{-1}\right)$. Lampl et al. ${ }^{17}$ have recently published a study comparing the two methods of administration of bupivacaine and fentanyl. Results were similar in the two groups, but fentanyl dosages were higher in the infusion group (no fentanyl reinjection was made until dilatation was full in the other group). This higher fentanyl dosage $(131 \pm 43.5 \mu \mathrm{g}$ versus $87 \pm 23.8 \mu \mathrm{g})$ docs not scem necessary as Milon ef $a{ }^{18}{ }^{18}$ have shown that increasing fentanyl dosage does not improve analgesia.

The present study suggests the advantage of continuous infusion. Indeed, there was some significant difference in favour of Group II in terms of dosage of the analgesic mixture $\left(5.32 \pm 0.95\right.$ versus $\left.7.70 \pm 1.35 \mathrm{ml} \cdot \mathrm{h}^{-1}\right)$. The course of labour was comparable (same interval between two contractions, same duration of delivery), and the number of forceps extractions and Caesarean sections was similar. There were no differences in dosage between the two groups. The assays of bupivacaine and fentanyl blood levels showed no significant difference between the two groups at any time. Nevertheless, it is interesting to note that, administered by continuous infusion, the dose selected was sufficient to provide satisfactory analgesia, did not cause drug-accumulation phenomena, and yielded blood concentrations identical to those for the first group at the end of the second stage of labour. None of the authors who assayed bupivacaine blood levels during continuous rate infusions for this indication ${ }^{4,7,19}$ have reported drug accumulation or tachyphylaxis. Since the majority of published studies concern either comparisons between bupivacaine and bupivacaine-fentanyl administered discontinuously ${ }^{17-19}$ or injection of bupivacaine alone at a constant ratc $2,4,5,7,20,21$ it is difficult to compare the doses chosen for this study with those reported.

By comparison with 0.25 per cent bupivacaine administered alone by continuous infusion, fentanyl allows a major decrease in dosage. When using bupivacaine alone, Rosenblatt et al. ${ }^{7}$ gave an initial bolus of $10 \mathrm{ml}$ followed by $10 \mathrm{ml} \cdot \mathrm{h}^{-1}$. Evans and Carrie ${ }^{5}$ employed an initial bolus of $7-10 \mathrm{ml}$ followed by $9.48 \mathrm{ml} \cdot \mathrm{h}^{-1}$ and Glover used a $10-\mathrm{ml}$ bolus followed by $6-8 \mathrm{ml} \cdot \mathrm{h}^{-1}$. Matouskova et al. ${ }^{23}$ reduced the initial dose to $7 \mathrm{ml}$, followed by only 5 $\mathrm{ml} \cdot \mathrm{h}^{-1}$. However, a supplementary injection was sometimes required during the course of labour, and delivery required supplementary analgesia by local infiltration or pudendal nerve block. Comparable results were reported by Taylor ${ }^{24}$ with $6 \mathrm{ml}^{-\mathrm{h}^{-1}}$ of 0.25 per cent bupivacaine. In the present study, no further injections were required to maintain high-quality analgesia, until the end of delivery.

Bupivacaine and fentanyl levels in maternal blood were always far below those considered to be potentially dangerous: $1.6 \mu \mathrm{g} \cdot \mathrm{ml}^{-1}$ bupivacaine in obstetrics according to Reynolds and Taylor (25) and $1-2 \mathrm{ng} \cdot \mathrm{ml}^{-1}$ fentanyl according to Hug and Murphy ${ }^{26}$ in a study performed in rats. As seen in Table IV, plasma concentrations of bupivacaine peaked 20 min after injection, but fentanyl did not show the same increase. This effect can be explained by differences in pharmacokinetics. The initial volume of distribution is larger for fentanyl than for bupivacaine. While transplacental passage of these two drugs is rapid, the maternal blood levels achieved were not dangerous, in view of published data. ${ }^{4-8}$ Examination of the neonates at birth did not show any deterioration by comparison with normal test values or any significant difference between the two groups. A complete neurosensorial study performed at the 30th minute did not show any difference between the two groups, nor with usual scores. Some authors ${ }^{7}$ consider that the continuous infusion technique increases the safety of cpidural analgesia, by limiting the risk of accidental injection of a large bolus into a vein or into the subarachnoid space. The initial bolus is still required (although the volume is smaller), and, as noted by Morison and Smedstad, ${ }^{9}$ this hypothetical advantage has not been substantiated. The risk of bacterial contamination due to repeated injections is probably diminished, and the use of an automatic infusion pump should reduce the difficulty of monitoring the patient for the first signs of recurrence of pain.

Evaluation of side-effects showed no difference between the two techniques; as is usually the case with a combination of bupivacaine-fentanyl, blood pressure remained stable. ${ }^{11,18,21,27}$ No clinical sign of respiratory depression was noted.

\section{Conclusions}

Comparison of two techniques for epidural administration of bupivacaine and fentanyl demonstrated a clear advantage for the continuous administration technique in terms of the quality of analgesia obtained: no recurrence of pain during dilation, analgesia sufficient for delivery with the parturient in a semirecumbent position at full dilatation, and no interference with contractions. The duration of labour was not prolonged, and there was no increase in the number of forceps cxtractions or Cacsarcan sections. Assay of blood bupivacaine and fentanyl showed no drug-accumulation. While the doses used with the constant infusion protocol were significantly lower, this did not have any apparent clinical consequences other than an increase of approximately five minutes in the latency time. This study thus confirmed the adyantage of continuous infusion in obstetric epidural analgesia. 


\section{References}

1 Seebacher J, Henry M, Galli-Douani $P$, Viars $P$. Epidural opioids in labour (pp. 111-4). In: Centennal Meeting of Regional Amaesthesia, Vienna, September 1984. Scort DB, McClure J, Wildsmith JAW, (Eds) Sodertalje (Sweden).

2 Davies $A O$, Fertes IW. A simple safe method for continuous infusion epidural analgesia in obstetrics. Can Andesth Soc J 1981; 28: 484

3 Writer WDR, James FM, and Wheelera S. Double-blind comparison of morphine and bupivacaine for continuous epidural analgesia in labour. Anesthesiology 1981; 54: 215

4 Glover $D J$. Continuous epidural analgesia in the obstetric patient: a feasibility using a mechanical infusion pump. Anaesthesia 1977; 32: 499 .

5 Evans KR, Carrie LE. Continuous epidural infusion of bupivacaine in labour: a simple method. Anaesthesia 1979:34: 310 .

6 Matouskova A, Hanson B. Continuous mini-infusion of bupivacaine into the epidural space during labour. Part II. Blood concentration of bupivacaine. Acta Obstet Gynecol Scand (suppl.) 1979; 83: 31.

7 Rosenblatr $R$, Wright $R$, Denson $D$, and Raj $P$. Continuous epidural infusions for obstetric analgesia. Regional Ancsthesia $1983 ; 8: 10$.

8 Cousin MT, Hentz T, Levron P, Pathier D. Le fentanyl par voie péridurale en obstétrique, effets maternels et foetaux et taux plasmatiques. Ann Fr Anesth Réanim (Abst.) 1983; 2: 201 .

9 Morison DH, Smedstad KG. Continuous epidural infusion for obstetric analgesia. Can Anaesth Soc J 1985; 32: 101.

10 Nadeau $S$, Elliot $R D$. Contimuous bupiyacaine infusion during labour: effects on analgesia and delivery. Can Anaesth Soc J 1983; 30: S71.

11 Jasson J, Talafre ML, Merceron L, Lirzin JD, Goujard J, Barrier $G$. Comparaison des effets de 2 fomes d'analgésic obstetricale sur la mère et sur l'enfant. Cah Anesthesiol 1983; $31: 9$.

t2 Duntett $C W$. New table for multiple comparison with a control. Biometrics 1964; 12: 482.

13 Sarndal F, Chaarani A, Mendoza R, Maneglia R, Pathier $D$, Cousin $M T$. Anesthésie péridurale obstétricale par bupivacaine-fentanyl. Cah Anesthesiol, 1983; 31: 399.

14 Chauvin M, Samii K, Schermann JM, Sandouk P. Pharmacologie des morphiniques administrés par voie péridurale et intrathécale. Nouv Presse med 1982; 11: 1003

15 Kanto J. Obstetric analgesia clinical pharmacokinetic considerations. Clin Pharmacokinetics 1986; 11: 283.

16 Bromage PR. Pettigrew RT, Crowell DE. Tachyphylaxis in epidural analgesia: I. Augmentation and decay of local aresthesia. J Clin Pharmacol 1969: 9: 30.

17 Lampl E, Leveque C. Maneglia R, Pathies F, Cousin MT.
Entretięn de l'analgésie obstétricale par perfusion continue dans l'espace péridural. Ann Fr Anesth Reanim 1986; 5: 351.

18 Milon $D$, Lavenac $G$, Noury $D$, Allain $H$, Van Den Driessche J, Saint-Marc $C$. Analgésie péridurale au cours du travai]: comparaison de trois associations, bupivacaïne-fentanyl et de la bupivacaïne seule. Ann Fr Anesth Rćanim 1986; 5: 18.

19 Laverac $G$, Noury D, Grall $J Y$, Le Bervet $J Y$. Analgésie obstétricale par voie péridurale à la seringue électrique. J Gynécol Obstết Biol Reprod (Paris) 1985; 14: 239.

20 Gaffud MP, Bansal P, Lawton C, Velasquez N, Watson $W A$. Surgical analgesia for cesarean delivery with epjdural bupivacaine and fentanyl. Anesthesiology 1986; 65: 331.

21 Justins DM, Francis D, Houlton PG, Reynolds F. A controlled trial of extradural fentanyl in labour. $\mathrm{Br} \mathrm{J}$ Anaesth 1982; 54: 409 .

22 Landais A, Darthout N, Kong-Ky BH, Sainl Maurice C. Association fentanyl-bupivacaïne péridurale pour l'analgésie obstérricale. Cah Anesthesiol 1983; 31: 297.

23 Matouskovu A, Hanson B, Elmen $H$. Continuous miniinfusion of bupivacaine into the epidural space during labour. Part III: a clinical study of 225 parturients. Acta Obstet Gynecol Scand (suppl.) 1979; 83: 43.

24 Taylor HJC. Clinical experience with continuous epidural infusion of bupivacaine at $6 \mathrm{ml}$ per hour in obstetrics. Can Anaesth Soc J 1983; 30: 227.

25 Reynolds F, Taylor G. Plasma concentrations of bupivacaine during continuous epidural analgesia in labour: the effect of adrenaline. Br J Anaesth 1971; 43: 436 .

26 Hug CC, Murphy MR. Tissue redistribution of feptanyl and termination of its effects in rats. Anesthesiology, 1981; 55: 369 .

27 Desprats SR, Mandry J, Grandjean H, Amar B, Pontonnier $G$, Lareng $L$. Analgésie péridurale au cours du travail: efude comparative de l'association fentanyl-marcaine et de la marcainne seule. J Gynéçol Obstet Biol Reprod (Paris) 1983: 12: 901 .

28 Cathelin $M$, Vignes $R$, Malki $M$, Viars $P$. Le citrate de fentanyl administre par voie intramusculaire chez l'homme conscient. Activité analgésique. Anesth Analg Réan 1980; 37: 257. 


\section{Résumé}

Une aralgésie péridurale a été réalisée avec un mélange bupivacaine-fentanyl en cours d'accouchement. Le travail était entrepris dans le but de comparer l'efficacité respective et les effets secondaires possibles de deux rechniques d'administrationt du mélange: injections itératives ou débit constant. Quarante quatre parturientes étaient réparties en deux groupes homogèntes quant cu numbre, aux donnêes anthropométriques cr à la parité. Les analgésies étaient débutées au même stade du travail. Le mélange associait $20 \mathrm{ml}$ de bupivacaīne d 0,25 pour cent sans adrénaline et $2 \mathrm{ml}(100 \mu \mathrm{g})$ de fentanyl. Dans le groupe I la dose de départ allait de 8 ou $10 \mathrm{ml}$ selon la vaille, les réinjections se faisant à la réapparition de la douleur avec un volume identique. Dans le groupe II, après une dose initiale de 4 ou $5 \mathrm{ml}$, une perfusion de $3 \mathrm{ml} \cdot \mathrm{h}^{-1}$ était débutée, et arrêtée à dilatation complète. L'analgésie était quantifiée grâce à une echelle de douleur; la pression artérielle et la fréquence respiratoire chez la mère et l'état des enfants d̀ la naissance étaient notés. Des dosages de bupivacaïne er de fentanyl étaient réalisés dans le sang veineux maternel chez 30 parturientes durant le déroulement du travail jusqu'à la fin de la dilisarion. Les résultats montrent dans le groupe II: un délai d' action plus long (de 5 min en moyenne), et une analgésie de qualité plus régulière. La meilleure qualité de l' analgésie ne peut pas étre expliquée par une différence de posologie: les doses sont significativement inférieures dans ce groupe malgré des accouchements de durée identique. Le déroulement du travail, l'étar maternel et celui des nouveaux-nés sont camparables dans les deux groupes. Enfin les dosages révèlent des taux sanguins non sigificativement différents entre les deux séries et sans signe d' accumulation.

La techrique d'administration à débit constant semble donc être intêressante puisqu' elle assure une analgésie de qualité régulière avec des posologies inférieures a celles nécessitées par des injections répétées. 